\title{
Phase Structure Evolution of the Fe-Al Arc-Sprayed Coating Stimulated by Annealing
}

\author{
Tomasz Chmielewski $^{1, *(1)}$, Marcin Chmielewski ${ }^{2}$, Anna Piątkowska ${ }^{2}$, Agnieszka Grabias ${ }^{2} \oplus$, Beata Skowrońska ${ }^{1}$ \\ and Piotr Siwek ${ }^{1}$ \\ 1 Institute of Manufacturing Technologies, Warsaw University of Technology, Narbutta Str. 85, \\ 02-524 Warsaw, Poland; beata.skowronska@pw.edu.pl (B.S.); siwek_piotr@wp.pl (P.S.) \\ 2 Łukasiewicz Research Network-Institute of Microelectronics and Photonics, Al. Lotników 32/46, \\ 02-668 Warsaw, Poland; Marcin.Chmielewski@imif.lukasiewicz.gov.pl (M.C.); \\ Anna.Piatkowska@imif.lukasiewicz.gov.pl (A.P.); Agnieszka.Grabias@imif.lukasiewicz.gov.pl (A.G.) \\ * Correspondence: tomasz.chmielewski@pw.edu.pl; Tel.: +48-22-849-9797
}

check for

updates

Citation: Chmielewski, T.;

Chmielewski, M.; Piątkowska, A.;

Grabias, A.; Skowrońska, B.; Siwek, P.

Phase Structure Evolution of the

Fe-Al Arc-Sprayed Coating

Stimulated by Annealing. Materials

2021, 14, 3210. https://doi.org/

$10.3390 /$ ma14123210

Academic Editor: Cezary

Senderowski

Received: 27 February 2021

Accepted: 3 June 2021

Published: 10 June 2021

Publisher's Note: MDPI stays neutral with regard to jurisdictional claims in published maps and institutional affiliations.

Copyright: (c) 2021 by the authors. Licensee MDPI, Basel, Switzerland. This article is an open access article distributed under the terms and conditions of the Creative Commons Attribution (CC BY) license (https:/ / creativecommons.org/licenses/by/ $4.0 /)$.

\begin{abstract}
The article presents the results of research on the structural evolution of the composite Fe-Al-based coating deposited by arc spray with initial low participation of in situ intermetallic phases. The arc spraying process was carried out by simultaneously melting two different electrode wires, aluminum and low alloy steel (98.6 wt.\% of Fe). The aim of the research was to reach protective coatings with a composite structure consisting of a significant participation of $\mathrm{Fe}_{\mathrm{x}} \mathrm{Al}_{\mathrm{y}}$ as intermetallic phases reinforcement. Initially, synthesis of intermetallic phases took place in situ during the spraying process. In the next step, participation of $\mathrm{Fe}_{\mathrm{x}} \mathrm{Al}_{\mathrm{y}}$ fraction was increased through the annealing process, with three temperature values, $700{ }^{\circ} \mathrm{C}, 800{ }^{\circ} \mathrm{C}$, and $900{ }^{\circ} \mathrm{C}$. Phase structure evolution of the Fe-Al arc-sprayed coating, stimulated by annealing, has been described by means of SEM images taken with a QBSD backscattered electron detector and by XRD and conversion electron Mössbauer spectroscopy (CEMS) investigations. Microhardness distribution of the investigated annealed coatings has been presented.
\end{abstract}

Keywords: Fe-Al type intermetallics; phase synthesis; arc sprayed coatings

\section{Introduction}

Transition iron aluminides are attractive coating materials with specific properties, especially in comparison with nickel or chromium-based materials. Fe-Al intermetallic systems have been among the most intensively studied over the last few decades [1] Many intermetallic applications of the $\mathrm{Fe}-\mathrm{Al}$ system relate to protective coatings made by different methods, like laser cladding [2,3], D-gun spray [4-6], flame spray [7,8], arc spray [9-11], cold gas spraying [12], and plasma transferred arc cladding [13], some using the strategy of employing the elemental powder materials [14]. Intermetallic phases, due to their advantages, are increasingly often used as a surface material, whose purpose is to work at high temperatures $[15,16]$. They are significantly resistant to oxidation, carburizing, and sulfation at high temperatures (up to $900{ }^{\circ} \mathrm{C}$ ) $[17,18]$. Additionally, they are highly resistant to erosion [19] and cavitation [20,21], and have relatively low density and low prices compared to corrosion-resistant [22,23] and acid-resistant steel [24], which require application expensive elements, such as $\mathrm{Cr}, \mathrm{Ni}$, Mo [25-27]. The intermetallics owe their special properties to their ordered structures with strong chemical bonds and simultaneous dense packing of atoms in crystal lattices, which leads to reduced diffusion velocity, creep resistance, and resistance to high-temperature corrosion [28-31].

There are reports in the literature that have described the processes of in situ manufacturing of intermetallic phases on a surface layer by the alloying of components $[32,33]$. Numerous cases of annealing-stimulated intermetallic synthesis are known in the literature [34-37], which could also be used as a part of the joining procedure [22]. The main 
disadvantage that limits the use of Fe-Al intermetallics is their brittleness at room temperature and the difficulty of shaping ready-made elements to desired dimensions by means of mechanical machining methods $[38,39]$. Due to the significant differences in properties like melting point and specific heat of $\mathrm{Fe}$ and $\mathrm{Al}$, it is difficult to obtain materials with a reproducible composition and homogeneous structure [40].

The method of producing a composite material using the Fe-Al intermetallic phase proposed in the article is a continuation of the procedure proposed in [10] and may constitute an alternative to the currently used solutions, which are usually much more expensive and based mainly on ready-to-use intermetallic powders [41,42].

\section{Materials and Experimental Procedure}

The initial investigation [10] and its results showed that a $0.5 \mathrm{~mm}$ thick and dense Fe-Al composite coating with uniformly distributed Fe and $\mathrm{Al}$ particles can be deposited by arc spraying onto the substrate of an S355 JR steel plate $\left(50 \times 100 \times 5 \mathrm{~mm}^{3}\right)$. The coating obtained included two main metallic phases based on the Fe (bcc) and Al (fcc) structure. However, Fe-Al precipitations have been revealed on the boundary grains as well as on the $\mathrm{Al}$ and Fe matrix. Volume fraction of intermetallic phases in the sprayed coating was too low to use XRD method to investigate them. Results showed that both SEM and EDS analyses confronted with Mössbauer spectroscopy analysis confirmed presence of FeAl intermetallic phases in the structure with varying atomic factors of iron and aluminum, including approximately $50-50 \%$ and $80-20 \%$ at the structure of the coating. Volume fraction of $\mathrm{Fe}_{\mathrm{x}} \mathrm{Al}_{\mathrm{y}}$ phases was between $7 \%$ and $10 \%$.

In this paper, an iron/aluminum composite coating deposited by arc spraying using iron and aluminum wires in the condition described in [10] was annealed at different temperature $\left(700{ }^{\circ} \mathrm{C}, 800{ }^{\circ} \mathrm{C}\right.$, and $900{ }^{\circ} \mathrm{C}$ ) values for $2 \mathrm{~h}$ to aim at increasing the volume fraction of iron aluminide intermetallic in composite coating. The parameters of the thermal annealing cycle were selected on the basis of a literature analysis [43-45]. Annealing processes have been realized in vacuumed atmospheres $\left(5 \times 10^{-5} \mathrm{Tr}\right)$ with an experimental vacuum chamber with induction heating, designed and built in the welding department of Warsaw University of Technology (Poland). After annealing, the samples were cooled and prepared for metallographic examination in the cross-section and on the surface. The specimens were grounded in the cross-section and on the coating's surface with abrasive paper up to 2000 grits, polished to obtain a mirror-finished surface for microstructure observation and chemical and phase composition analysis. The composite, multi-phase Fe-Al arc-sprayed coating on the steel substrate after annealing was analyzed via scanning electron microscope Auriga produced by the Zeiss company (Oberkochen, Germany). The microstructure and phase structure of the coating after annealing were investigated by using SEM, XRD, and Mössbauer spectroscopy analogously to the study its structure before annealing for comparison. X-ray diffraction measurements were performed using the Siemens D500 powder diffractometer (Siemens, Munich, Germany), equipped with a highresolution semiconductor Si: $\mathrm{Li}$ detector and $\mathrm{K} \alpha 1,2 \mathrm{Cu}$ radiation $\lambda=1.5418$ Á. Conversion electron Mössbauer spectroscopy (CEMS) has been carried out using a constant acceleration home-made Mössbauer spectrometer (designed and built by Łukasiewicz Research Network-Institute of Microelectronics and Photonics) with integrated gas flow electron counter. Measurements were performed at room temperature with the use of a ${ }^{57} \mathrm{Co}-\mathrm{in}-\mathrm{Rh}$ source. The annealed coatings were probed up to about $200 \mathrm{~nm}$ in depth. As a supplement to the assessment of structural changes, the distribution of the coating's hardness in the cross-section along four parallel lines up to the surface layer of substrate material were performed according to the Vickers method using the Leitz-Wetzlar microhardness tester (LEICA, Wetzlar, Germany) (load $100 \mathrm{~g}$ for $10 \mathrm{~s}$ ).

\section{Results and Discussion}

3.1. SEM Investigation of Annealed Coatings

SEM images taken throughout the entire coating (Figure 1) revealed a large variety 
of phases and their generally lamellar distribution nature, specific to thermally sprayed coatings [46,47]. The aluminum wire is chemically active in the arc spraying process, such that melted particles are already oxidized in metallization stream and the obtained coatings always contain oxide films, mainly present in the areas between of lamellar grains of higher aluminum content.

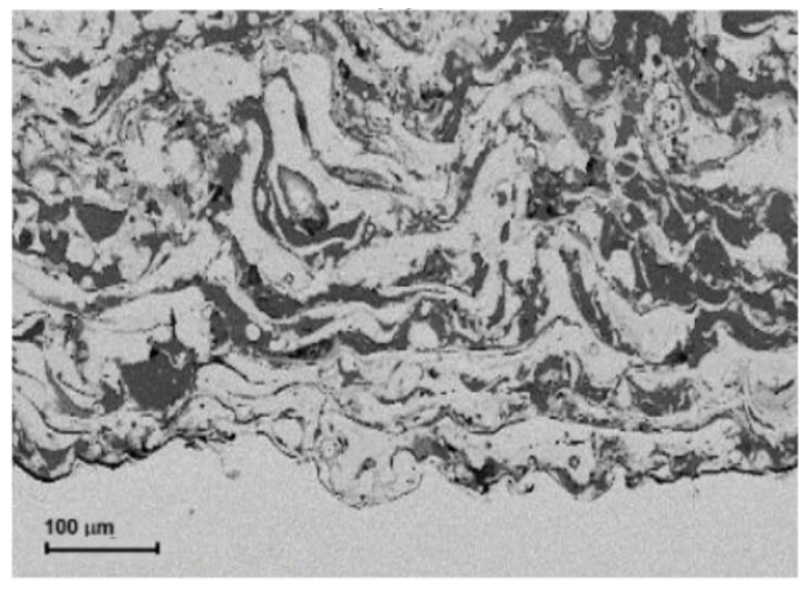

(a)

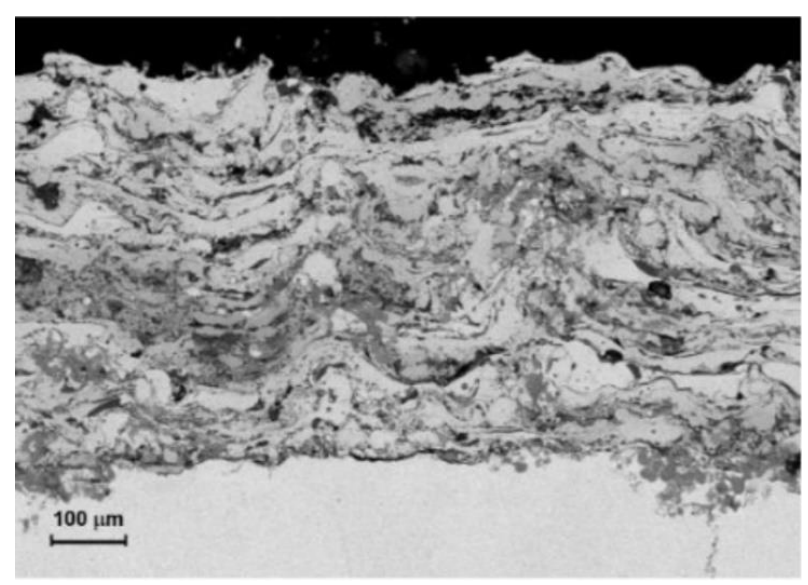

(c)

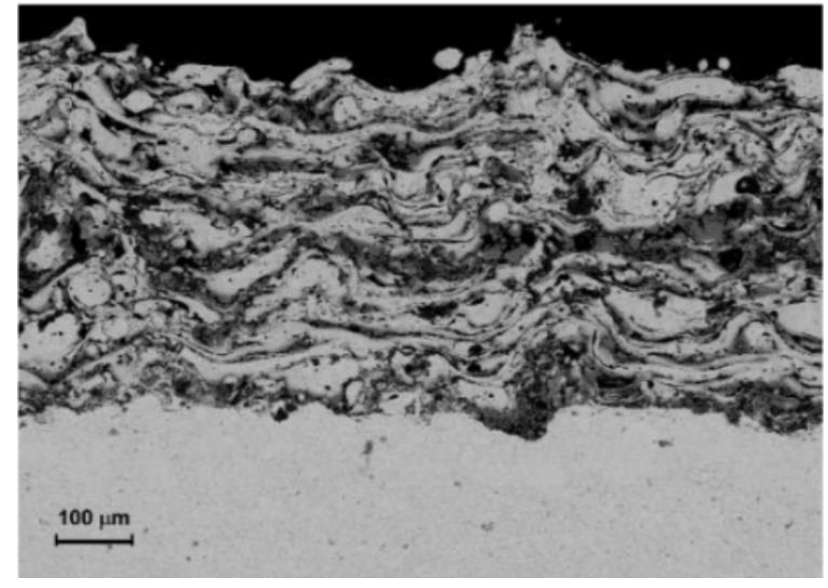

(b)

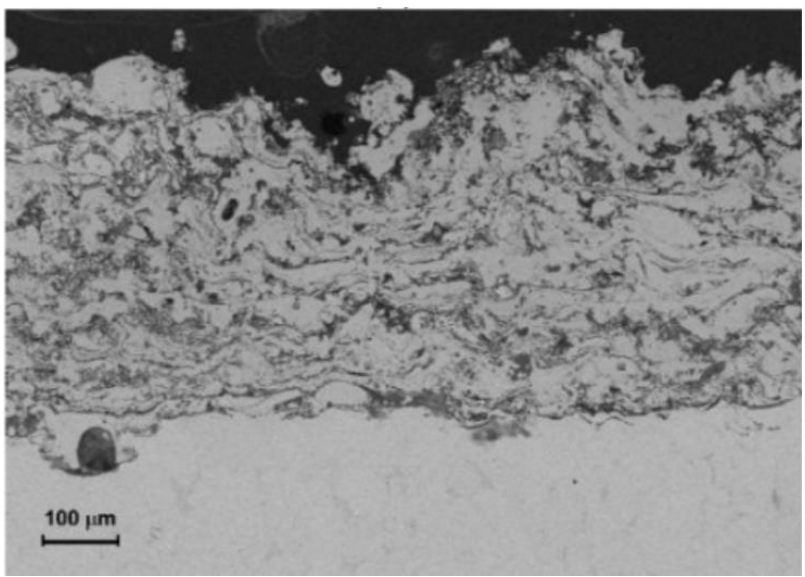

(d)

Figure 1. SEM/QBSE images of as-arc-sprayed Fe-Al-type coating (a), and after annealing for $2 \mathrm{~h}$, at respectively: $(\mathbf{b}) 700^{\circ} \mathrm{C}$, sample 1 ; (c) $800{ }^{\circ} \mathrm{C}$, sample 2 ; (d) $900{ }^{\circ} \mathrm{C}$, sample 3 .

As a result of high kinetic energy, temperature, and the speed of melted particles in the arc-spraying process, the Fe-Al-type coatings that were about $500 \mu \mathrm{m}$ thick showed a lamellar microstructure with an inhomogeneous phases distribution where a few spherical non-molten particles were visible (Figure 1a). Based on SEM/QBSE images, different shades of gray were observed for indicated phases with different atomic masses in the backscattered electron (QBSE) detector.

Various shades of gray areas in the SEM/QBSE images correspond to different phasespredominant $\mathrm{Fe}(\mathrm{Al})$ solid solution with high iron is indicated by the lightest grains and the aluminum-rich phases, including oxides and spinels, are represented by the darkest grains in Figure 1a.

The local occurrences of disordered and dispersed intermetallic Fe-Al-type phases in various $\mathrm{Al}$ content must be also emphasized (presented as the varied degree of grayness in individual grains in the QBSE examination and slightly less bright than these high-Al grains-Figure 1a). 
The high degree of chemical inconsistency of the arc-sprayed Fe-Al-type coating also proves its intermetallic phase inhomogeneity, especially when one takes into consideration the fact that a big range of acceptable changes in the alloying elements contents in the Fe-Al intermetallic phase solutions [46,47]. The comparative analysis in the cross-sections of the Fe-Al type coating (Figure 1) indicate that the Fe-Al arc-sprayed coating (Figure 1a) is not uniform in the phase structure and morphology throughout its thickness [10]. However phase structure of the coating has been significantly changed, in the direction of higher homogeneity, after annealing sample 1 at $700{ }^{\circ} \mathrm{C}$ (Figure 1b), sample 2 at $800^{\circ} \mathrm{C}$ (Figure 1c), and sample 3 at $900{ }^{\circ} \mathrm{C}$ (Figure $1 \mathrm{~d}$ ).

As the Fe-Al type arc-sprayed coatings were annealing at high temperatures, the thermal and hardness stability of the Fe-Al type intermetallic coating (such as the change in the morphology and chemical composition of the lamellar structure, phase change susceptibility, and the degree of strengthening of the coating) was analyzed after heating at a high-temperature (respectively $700{ }^{\circ} \mathrm{C}, 800^{\circ} \mathrm{C}$, and $900{ }^{\circ} \mathrm{C}$ ) for $2 \mathrm{~h}$.

\subsection{EDX Measurements}

\subsubsection{Arc-Sprayed Fe-Al-Type Coating Annealed at $700{ }^{\circ} \mathrm{C}$}

The basis for identification of the structural analysis and inhomogeneity of the chemical composition (phase composition) in the arc-sprayed Fe-Al type coatings after they were annealed at high temperatures were the EDX results of point and linear microanalysis of the chemical composition, as well as mapping of $\mathrm{Fe}, \mathrm{Al}$, and $\mathrm{O}$ elements.

Based on the results of SEM/EDX point microanalysis, it was shown (Figure 2) that the layered arrangement of grains of the arc Fe-Al-type coating annealed at $700{ }^{\circ} \mathrm{C}$ revealed a considerably varied chemical composition with an extended range of solid solution from about 6 to 37 at.\% Al (Table 1). This wide range of compositions implies the occurrence of grains based on the low-aluminum $\mathrm{Fe}(\mathrm{Al})$ solid solution grains observed as the bright gray areas in the BSE image (p1 and p2 in Figure 2).

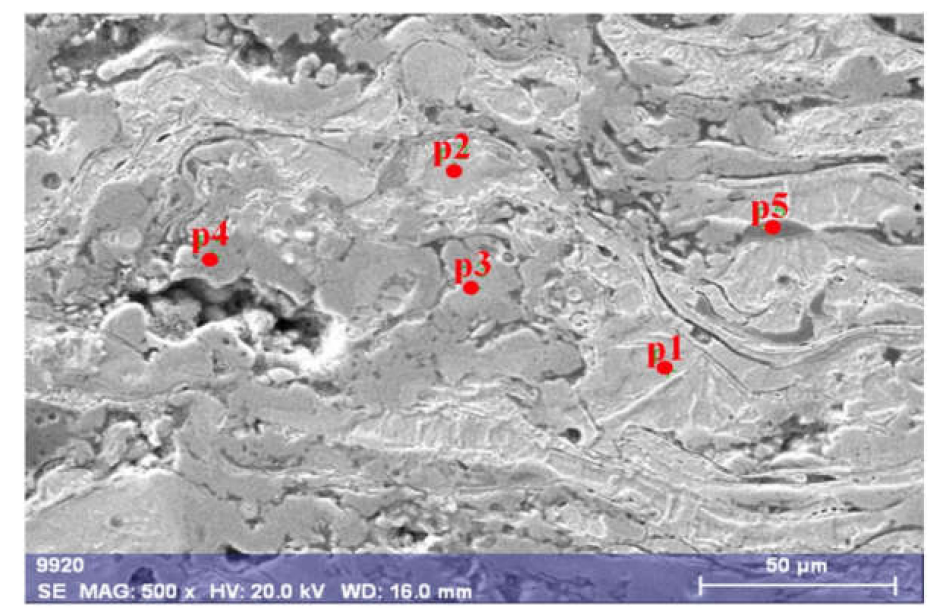

Figure 2. Microstructure of arc-sprayed Fe-Al-type intermetallic coating after annealing at $700{ }^{\circ} \mathrm{C}$ for $2 \mathrm{~h}$ with hypothetical phase identification based on results of EDS point analysis (in Table 1).

Table 1. Chemical composition of as-arc-sprayed Fe-Al-type coating after annealing at $700{ }^{\circ} \mathrm{C} / 2 \mathrm{~h}$ based EDX point microanalysis according to Figure 2.

\begin{tabular}{cccccccccc}
\hline Designation of Grain Area & \multicolumn{9}{c}{ Content, at. \% } \\
\cline { 2 - 9 } According to Figure 2 & $\mathbf{C}$ & $\mathbf{O}$ & $\mathbf{A l}$ & $\mathbf{S i}$ & $\mathbf{M n}$ & $\mathbf{F e}$ & Au & Occurrence \\
\hline p1 & $\sim 9$ & $\sim 1$ & 6.47 & 0.48 & 0.66 & 81.49 & 0.15 & often \\
p2 & $\sim 10$ & - & 7.69 & 0.84 & 0.60 & 80.62 & 0.13 & often like p1 \\
p3 & $\sim 12$ & $\sim 19$ & 24.90 & 0.55 & 0.72 & 41.85 & 0.10 & rare & rare like p3 \\
p4 & $\sim 4$ & $\sim 51$ & 6.33 & 0.29 & 0.38 & 36.25 & 0.09 & very rare \\
p5 & $\sim 15$ & $\sim 35$ & 35.76 & 0.14 & 0.64 & 12.87 & 0.09 &
\end{tabular}


Annealing at $700{ }^{\circ} \mathrm{C}$ for $2 \mathrm{~h}$ also caused a local presence of disordering secondary solution based on Fe-Al phases ranging from 25 to 36 at.\% $\mathrm{Al}$ and a significant content of oxygen (p3 and p5 in Figure 2). However, near some Fe-Al phases, depletion of $\mathrm{Al}$ entailed a local occurrence of oxides in the form of spinels (p4 in Figure 2), as well as aluminum oxides created between lamellar grains (p5 in Figure 2) where Fe was doped from the matrix of $\mathrm{Fe}-\mathrm{Al}$ intermetallic material.

In the discussion of the EDX analysis, the identified trace elements were not taken into account (Table 1), as the contaminations of $\mathrm{Si}, \mathrm{Mn}$, and $\mathrm{Au}$ could be caused by polishing of the samples as well as sputtering with a thin Au layer about $10 \mathrm{~nm}$ thick in order to avoid issues with the electrical charge of the primary electron beam in the preparation of the cross-sections of the samples that were obtained using a non-conductive resin as a matrix.

The relative content of these contaminations was below 1 at. $\%$ and can be considered as negligible. In the case of light elements such as oxygen and carbon, the analysis was semi-quantitative. The significant presence of carbon was most probably related to the preparation of cross-sections of the samples, where during the polishing process the resin could be transferred to the studied surface of the sample.

The basis for identification of oxides in the Fe-Al-type coating after annealing at $700{ }^{\circ} \mathrm{C}$ were the results of a linear microanalysis of the chemical composition (Figure 3), as well as mapping of $\mathrm{Fe}, \mathrm{Al}$, and $\mathrm{O}$ elements (Figure 4), which proved that oxygen, apart from oxide spinels, is mainly present in the areas of grains of higher aluminum content (imaged as dark grey and grey), but also in the light grey areas identified as disordering secondary solid solution based on Fe-Al phases with decreased Al content.

Additionally, the results of the linear EDS measurements (Figure 3a,b) performed on the representative surface of the Fe-Al-type coating annealed at $700{ }^{\circ} \mathrm{C}$ showed very different proportions of the $\mathrm{Al}-\mathrm{Fe}$ elemental ranging from 10 to 50 at.\% $\mathrm{Al}$ along the line with a length of approx. $20 \mu \mathrm{m}$. The linear EDX results of changes in the proportions and chemical compositions at the grain boundary cross-sections of the coatings are shown in Figure $3 \mathrm{c}$, d. In the region marked with the yellow arrow, the phase composition of roughly 50 at. $\%$ Fe was observed up to about first $10 \mu \mathrm{m}$. The measurement along the green arrow indicates at one end Fe oxide, whereas on the other end there is $\mathrm{Al}$ oxide. In the middle, a mixed Fe-Al-O phase is observed.

This is a confirmation of the fact that the lamellar grains created in the arc-spraying conditions after annealing at $700{ }^{\circ} \mathrm{C}$ exhibited certain composite features due to the different Fe-Al type phases as components of the structure inherited from the arc-spraying wire material, only with inconsiderable evidence of the phase transformation during heating at $700{ }^{\circ} \mathrm{C}$ for $2 \mathrm{~h}$. The aluminum wire is chemically active in the arc-spray process, such that all melted particles are already oxidized in the obtained coatings and always contain oxide films inside the coating and at the internal interfaces. It is mainly formation of the oxide films (the oxidized blue areas of the coating structure on EDX maps, Figure 4a) that brings phase transformation during heating at $700{ }^{\circ} \mathrm{C}$ for $2 \mathrm{~h}$.

\subsubsection{Arc-Sprayed Fe-Al-Type Coating Annealed at $800{ }^{\circ} \mathrm{C}$}

After heat treatment at $800{ }^{\circ} \mathrm{C}$ for $2 \mathrm{~h}$, the SEM/EDX results (Figures 5 and 6) revealed the inhomogeneous lamellar structure characteristic-like arc spraying with a varied chemical composition based on the Fe-Al-type phases and oxides, identified mainly in the interlamellar grain boundaries of the coating (Figures 5 and 6). Based on the results of scanning electron microscopy and point EDX microanalysis and mapping, it was shown (Figures 5 and $6 \mathrm{a}, \mathrm{b}$ ) that the grains based on the Fe-Al phases had the range of secondary solid solution from $\sim 14$ to $\sim 33$ at. $\% \mathrm{Al}$ (Table 2). 


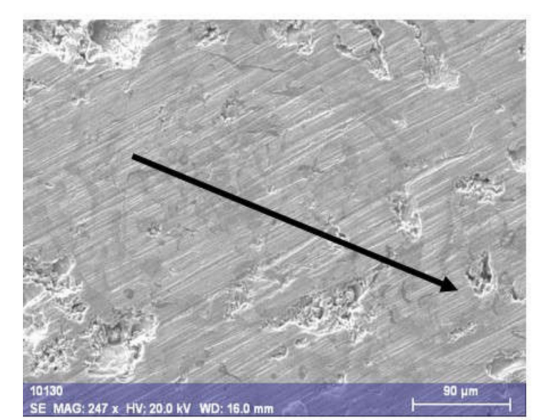

(a)

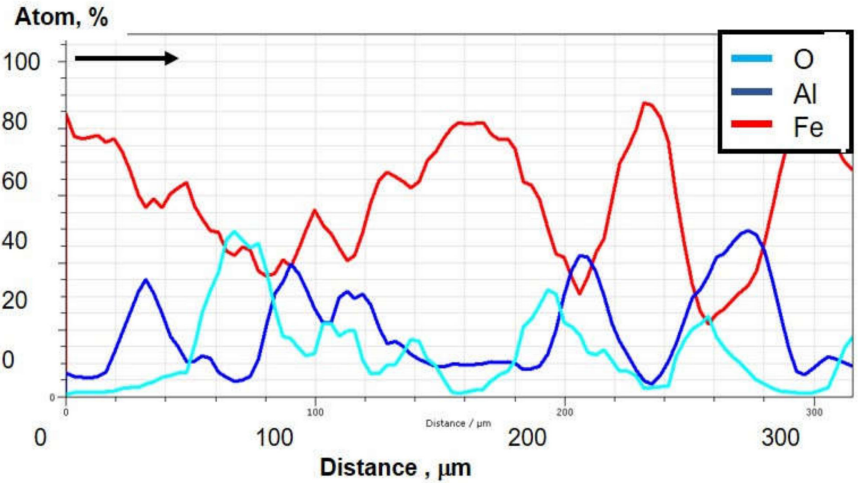

(b)
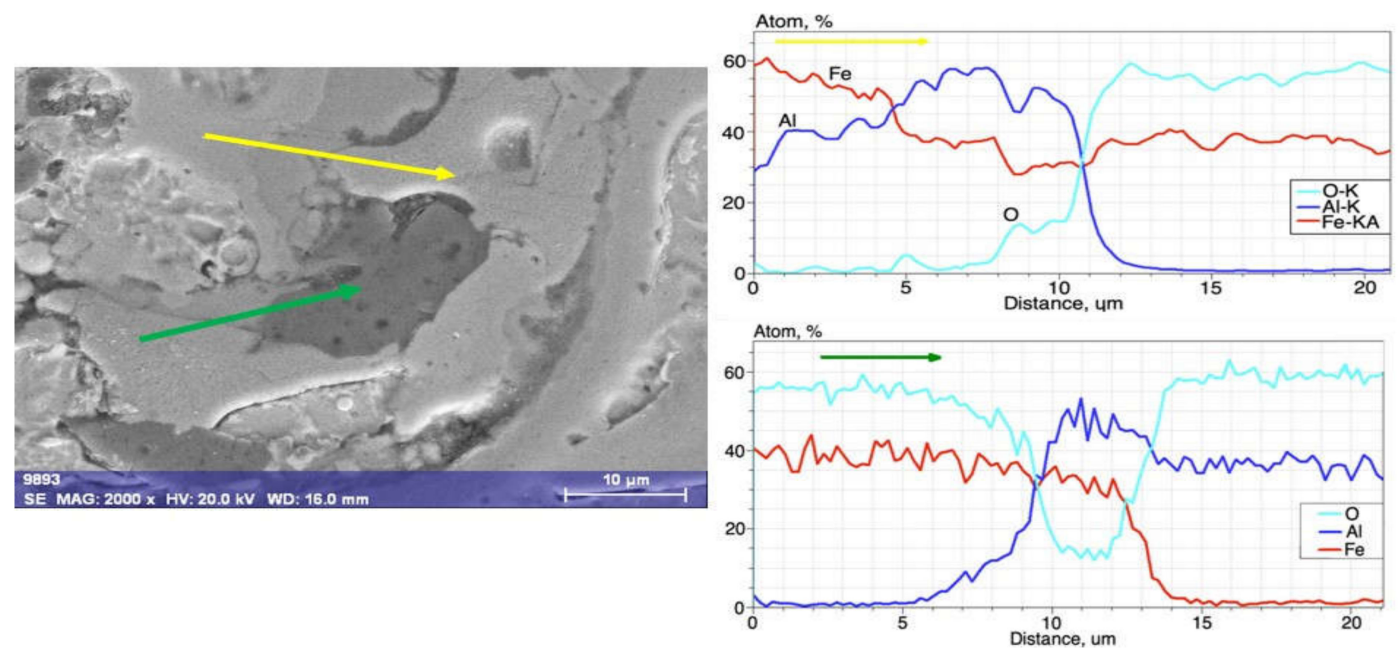

(c)

(d)

Figure 3. Linear chemical analysis of as-arc-sprayed Fe-Al-type coating after annealing at $700{ }^{\circ} \mathrm{C} / 2 \mathrm{~h}$ : (a) SE image of the surface of the coating, (b) linear distribution of elements along the black arrow marked on Figure 3a, (c) SE image with details of the layer cross-section, (d) linear distribution of elements along the black narrow marked on Figure 3a, (c) SEM image with details of the layer cross-section, (d) linear distribution of elements along the yellow and green arrows marked on Figure 3c.

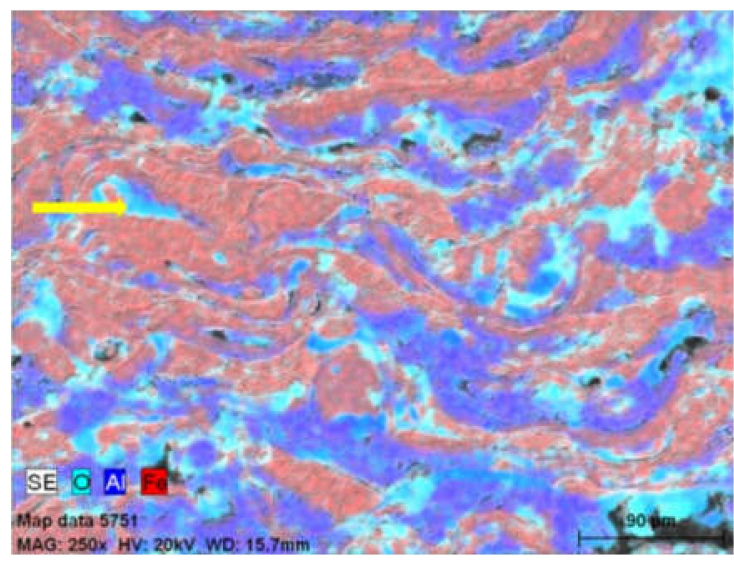

(a)

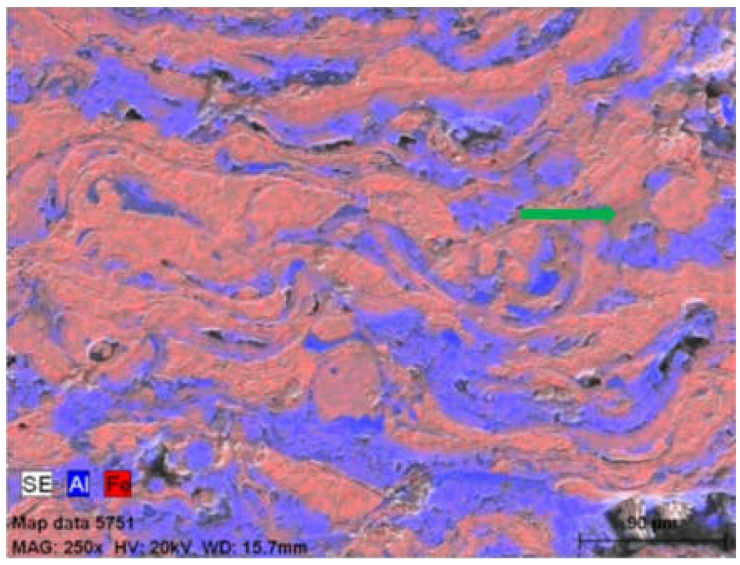

(b)

Figure 4. EDX maps of elemental distribution in cross-section of the Fe-Al-type coating annealed at $700{ }^{\circ} \mathrm{C}$ : $(\mathbf{a}) \mathrm{O}, \mathrm{Al}, \mathrm{Fe}$; (b) Al, Fe. 


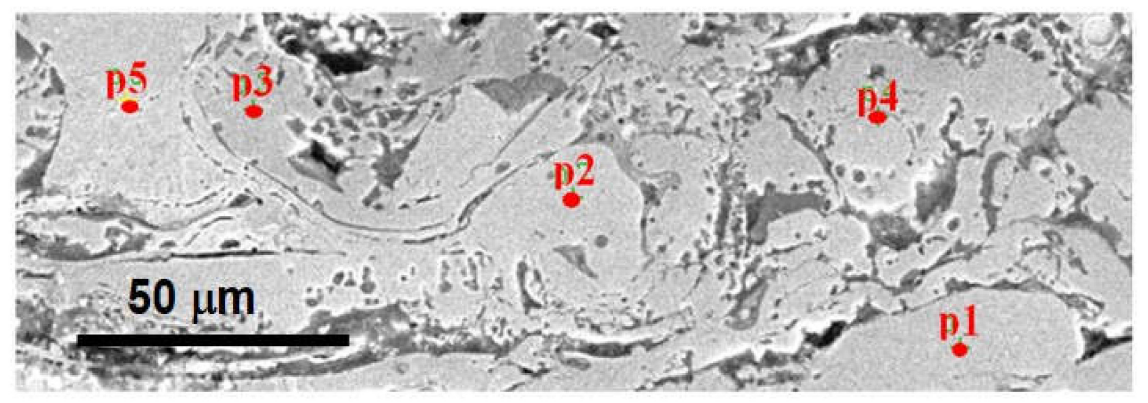

Figure 5. Microstructure of arc-sprayed Fe-Al-type intermetallic coating after annealing at $800{ }^{\circ} \mathrm{C}$ for $2 \mathrm{~h}$ with hypothetical phase identification based on results of EDX point analysis (in Table 2).

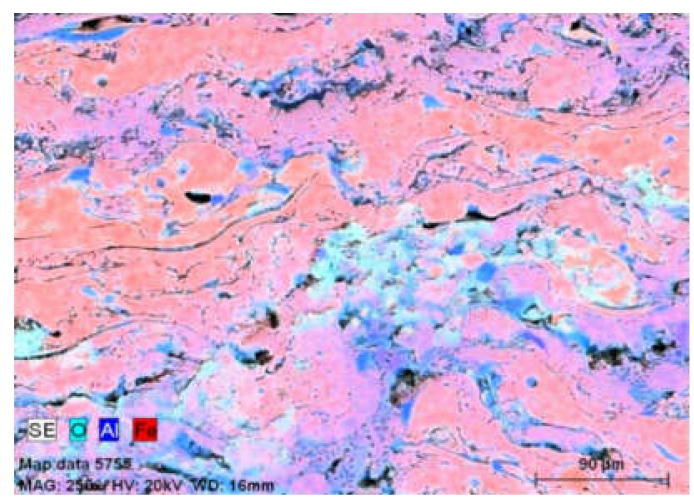

(a)

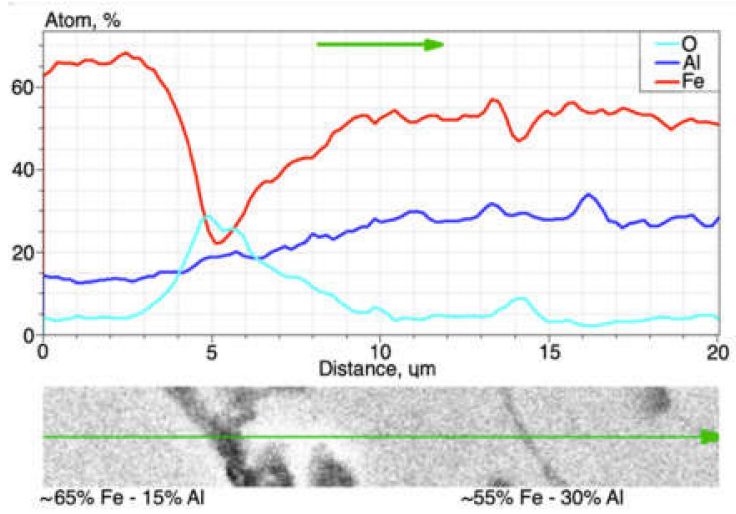

(c)

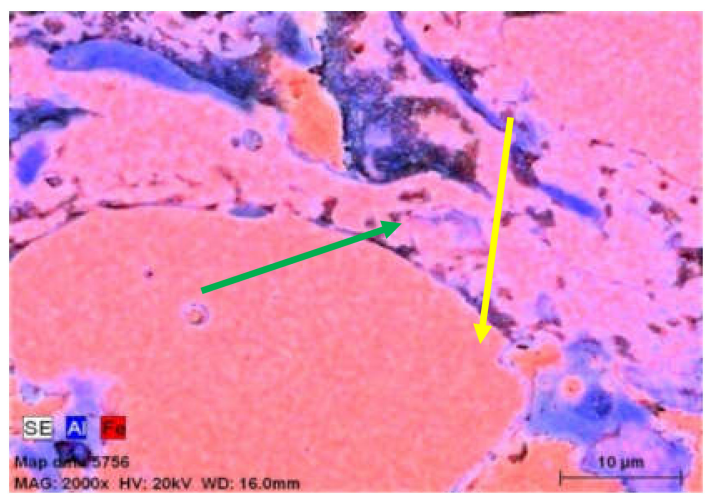

(b)

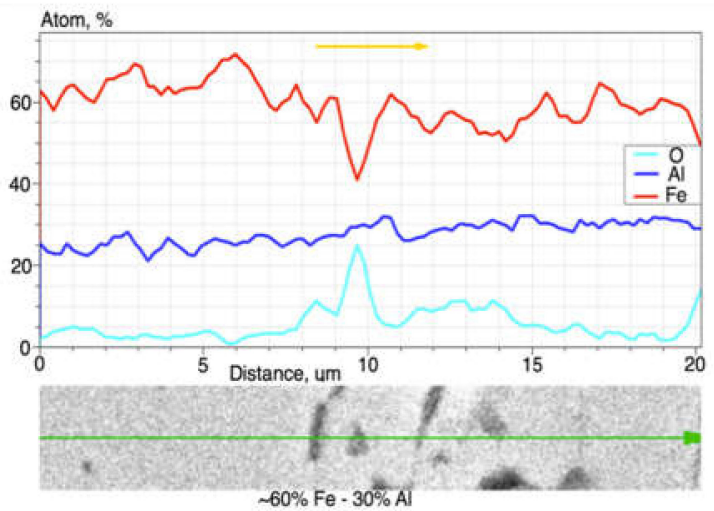

(d)

Figure 6. EDX results of elements distribution in cross-section of the coating annealed at $800{ }^{\circ} \mathrm{C}$ : maps of (a) $\mathrm{O}, \mathrm{Al}$, and $\mathrm{Fe}$ and (b) $\mathrm{Al}$ and $\mathrm{Fe}$, as well as plots of the linear distribution of elements along two lines, respectively-(c) green and (d) yellow-as marked on (b).

Table 2. Chemical composition of as-arc-sprayed Fe-Al-type coating after annealing at $800{ }^{\circ} \mathrm{C} / 2 \mathrm{~h}$ based on EDX point microanalysis according to Figure 5.

\begin{tabular}{cccccccccc}
\hline Designation of Grain Area & \multicolumn{8}{c}{ Content, at.\% } \\
\cline { 2 - 9 } According to Figure 5. & C & O & Al & Si & Mn & Fe & Au & Occurrence \\
\hline p1 & $\sim 9$ & - & 21.60 & 0.92 & 0.57 & 67.49 & 0.08 & often \\
p2 & $\sim 8$ & $\sim 3$ & 17.34 & 0.70 & 0.39 & 69.55 & 0.07 & often \\
p3 & $\sim 9$ & - & 32.86 & 0.40 & 0.32 & 56.63 & 0.21 & rare & often \\
p4 & $\sim 9$ & - & 25.84 & 0.74 & 0.53 & 63.18 & 0.09 & medium \\
p5 & $\sim 13$ & $\sim 8$ & 13.93 & 0.63 & 0.43 & 62.99 & 0.26 &
\end{tabular}


The share of the dark phase related to $\mathrm{Al}$ and the $\mathrm{Fe}-\mathrm{Al}$ intermediate phases were increased. Areas in the pink color in Figure 6a,b were suitable for Fe-Al phases. The more violet the color of the surface in the structure, the greater the proportion of aluminum. The SEM/EDX results shown in Figures 5 and 6 and Table 2 allowed identification of the fact that in the Fe-Al-type coating annealed at $800^{\circ} \mathrm{C} / 2 \mathrm{~h}$, the most common phase was low-aluminum $\mathrm{Fe}_{3} \mathrm{Al}$ at.\%, as shown by the disordered secondary solid solution observed in the brightest areas of the SEM/BSE image (Figure 5) and in the pink Fe- and Al-mapping (Figure $6 \mathrm{a}, \mathrm{b})$. In the plots of the variations of the aluminum, oxygen, and iron in the linear EDX analyses (Figure 6c,d), the peak oxygen oscillations corresponded to the passage of the analyzing beam of electrons through the oxides, which was the inherent structural component of the Fe-Al-type coating annealed at $800^{\circ} \mathrm{C} / 2 \mathrm{~h}$.

\subsubsection{Arc-Sprayed Fe-Al-Type Sample 3 Annealed at $900{ }^{\circ} \mathrm{C}$}

The morphology of arc-sprayed Fe-Al-type coating annealed at $900{ }^{\circ} \mathrm{C}$ for $2 \mathrm{~h}$ was related to the presence of dispersed intermetallic phases in the various stages of ordering (depending on the $\mathrm{Al}$ content), as shown in Figures 7 and 8, where the different phases on the cross-section of the coating were revealed.

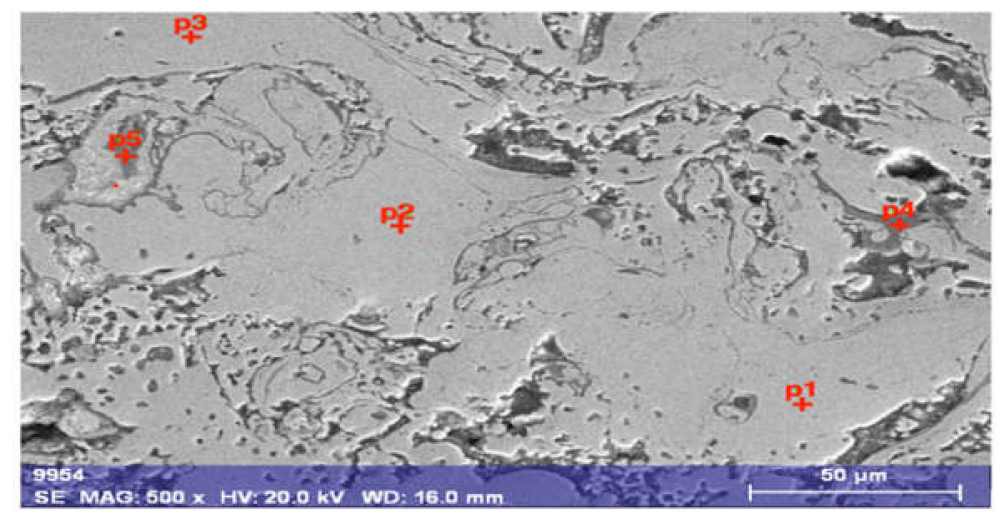

Figure 7. Microstructure of arc-sprayed Fe-Al-type intermetallic coating after annealing at $900{ }^{\circ} \mathrm{C}$ for $2 \mathrm{~h}$ with hypothetical phase identification based on results of EDS point analysis (in Table 3).

Table 3. Chemical composition of as-arc-sprayed Fe-Al-type coating after annealing at $900{ }^{\circ} \mathrm{C} / 2 \mathrm{~h}$ based EDX point microanalysis according to Figure 7.

\begin{tabular}{|c|c|c|c|c|c|c|c|c|}
\hline \multirow{2}{*}{$\begin{array}{l}\text { Designation of Grain Area } \\
\text { According to Figure } 7\end{array}$} & \multicolumn{8}{|c|}{ Content, at. $\%$} \\
\hline & $\mathrm{C}$ & $\mathbf{O}$ & Al & Si & Mn & $\mathrm{Fe}$ & $\mathrm{Au}$ & Occurrence \\
\hline $\mathrm{p} 1$ & $\sim 15$ & - & 21.86 & 0.55 & 0.64 & 61.78 & 0.10 & often \\
\hline p2 & $\sim 9$ & - & 21.64 & 0.79 & 0.66 & 67.67 & 0.15 & often like p1 \\
\hline p3 & $\sim 8$ & - & 23.57 & 0.48 & 0.63 & 67.11 & 0.14 & often like p1 \\
\hline $\mathrm{p} 4$ & $\sim 6$ & $\sim 56$ & 34.62 & 0.21 & 0.94 & 1.22 & 0.05 & rare -precipitation \\
\hline p5 & $\sim 4$ & $\sim 55$ & 34.47 & 0.04 & 0.23 & 4.47 & 0.08 & rare \\
\hline
\end{tabular}

After heat treatment, the microstructure lost its lamellar-like structure, which appeared to have more homogeneity at this point but was still not quite regular. In the middle area of the EDX map in Figure 8a, the phase indicated by the red color was rich in Fe and, it coexisted with the dominant Fe-Al phase in bright weight contrast marked in pink in the EDX Fe and Al maps. On the other hand, the Al-rich phase occurred sporadically, mainly crystallized as narrow lamellas between the matrix areas, and it was also highly oxidized, as presented on Figure 8c. 


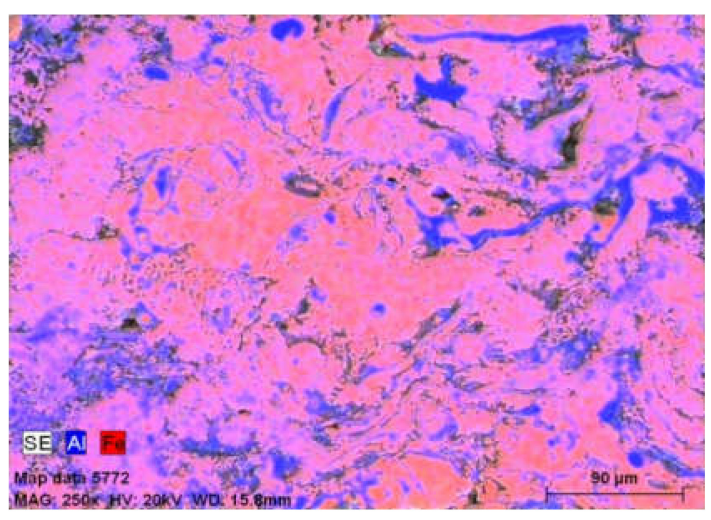

(a)

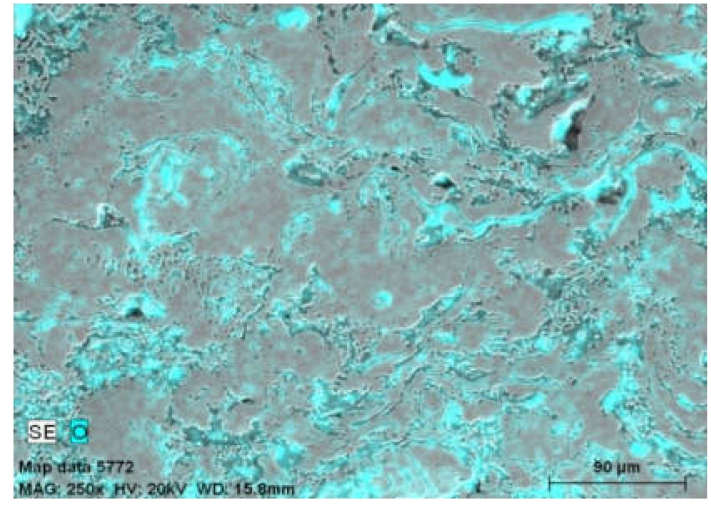

(b)

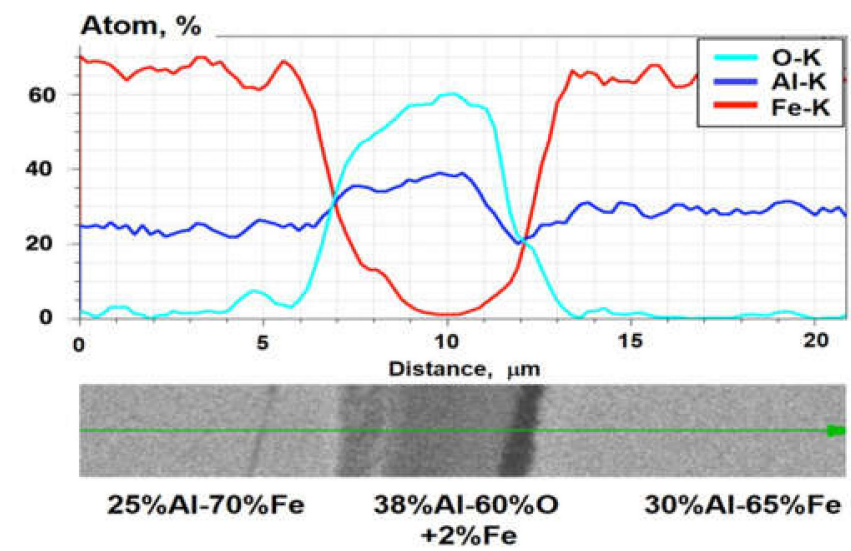

(c)

Figure 8. EDX results of elemental distribution in cross-section of the coating annealed in $900{ }^{\circ} \mathrm{C}$ : maps of (a) $\mathrm{Al}$ and $\mathrm{Fe}$ and (b) $\mathrm{O}$, as well as (c) plots of the linear distribution of elements along green line.

\subsection{XRD Analysis}

In order to analyze the phase structure of the coatings, the XRD analysis was performed for three representative samples annealed at the temperatures of $700{ }^{\circ} \mathrm{C}, 800^{\circ} \mathrm{C}$, and $900{ }^{\circ} \mathrm{C}$.

Figure 9 presents a diffraction pattern that implies that the phase structure of the studied coating after annealing at $700{ }^{\circ} \mathrm{C}$ consisted mainly of the metallic phase based on the bcc Fe phase, which was accompanied by the intermetallic $\mathrm{Al}_{5} \mathrm{Fe}_{2}$ phase. The dominant bcc phase was most probably an $\mathrm{Fe}(\mathrm{Al})$ solid solution with a substantial content of the solvent, which was suggested by a significantly larger value of the lattice constant as compared to pure Fe. A small fraction of an iron oxide phase with the wustite-like structure $(\mathrm{FeO})$ was also seen in the XRD pattern. The volume fraction of this phase in the structure was approximately $5 \%$; however, after annealing at 800 and $900{ }^{\circ} \mathrm{C}$, it dropped below the level of XRD detection.

The XRD pattern obtained for the coating annealed at $800{ }^{\circ} \mathrm{C}$ is shown in Figure 10. The phase structure of the analyzed coating consisted of a substantial fraction of the FeAl intermetallic phase, as well as the bcc Fe-based metallic phase and a metastable Al86Fe14 phase. Figure 11 presents the diffraction pattern of the sample annealed at $900^{\circ} \mathrm{C}$, which revealed two main phases. The dominant intermetallic FeAl phase coexisted with the bcc Fe-based metallic phase. 


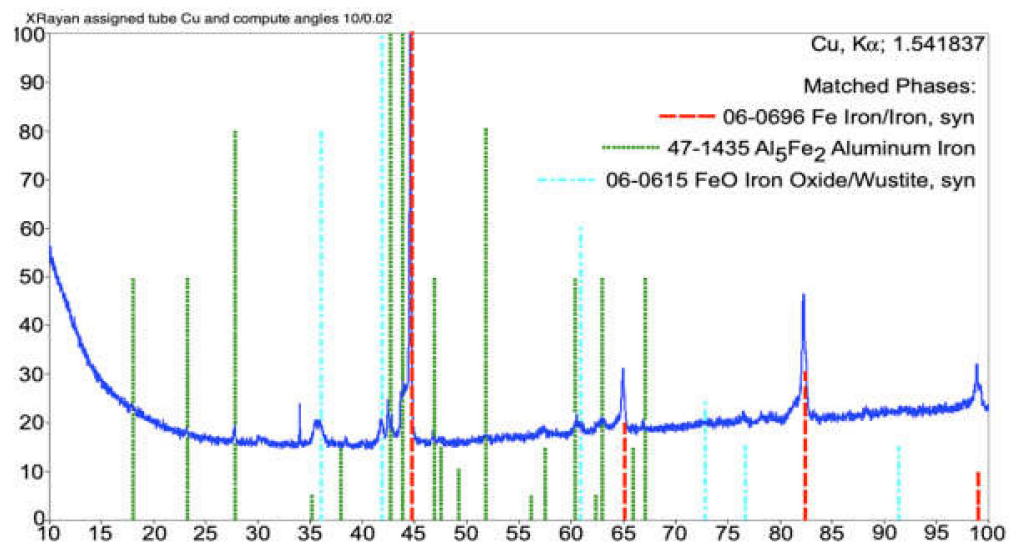

Figure 9. XRD diffraction pattern of the arc-sprayed Fe-Al coating after $700{ }^{\circ} \mathrm{C}$ annealing.

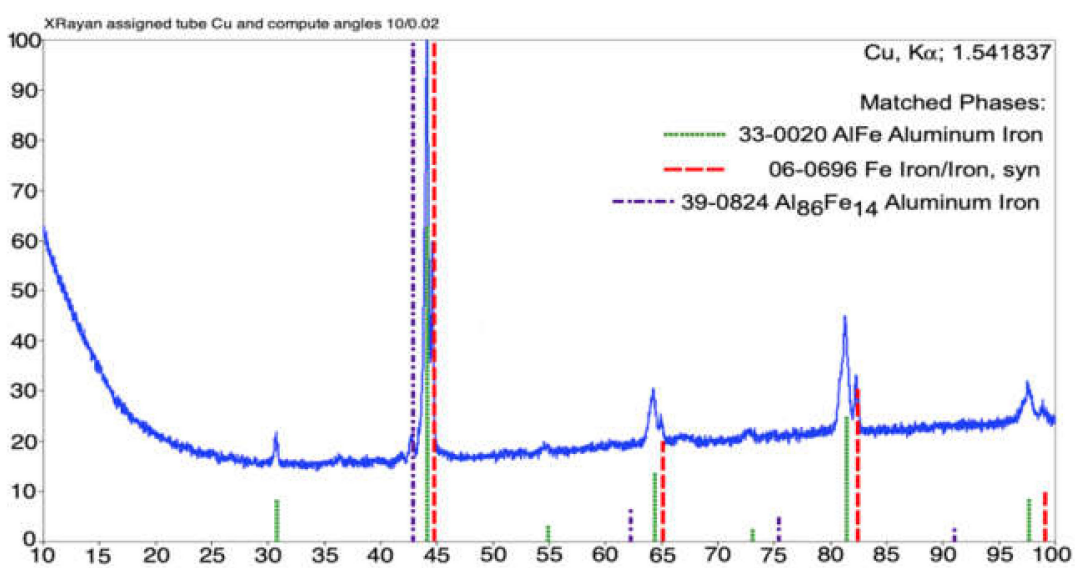

Figure 10. XRD diffraction pattern of the arc-sprayed $\mathrm{Fe}-\mathrm{Al}$ coating after $800^{\circ} \mathrm{C}$ annealing.

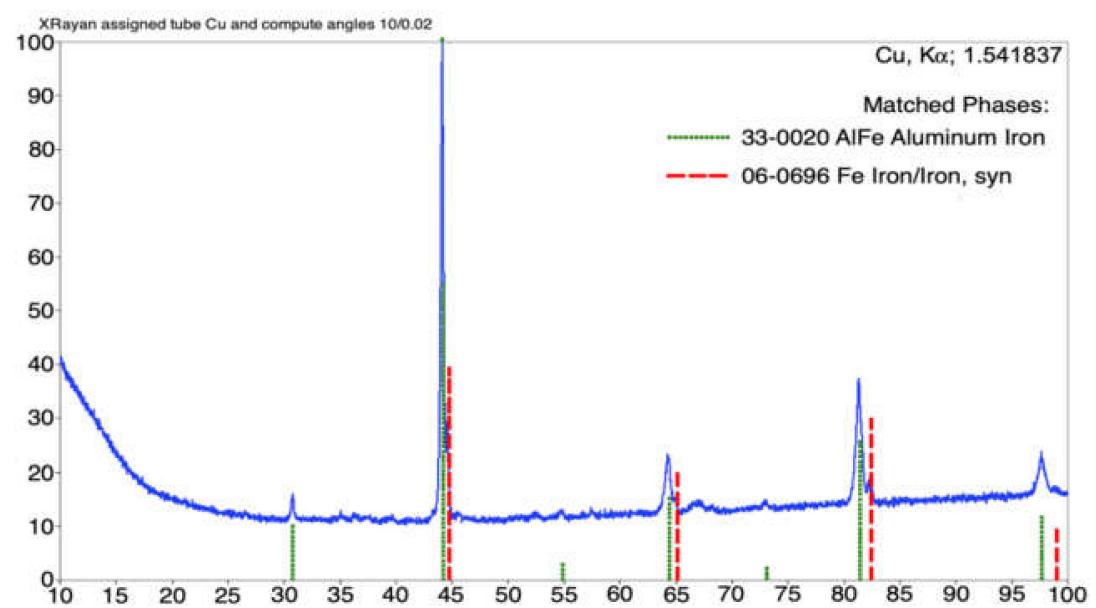

Figure 11. XRD diffraction pattern of the arc-sprayed Fe-Al coating after $900{ }^{\circ} \mathrm{C}$ annealing.

The XRD studies were complemented by conversion electron 57Fe Mössbauer spectroscopy measurements, which provided additional information regarding the atomic environment of iron atoms in the studied coatings.

\subsection{Mössbauer Spectroscopy Results of Annealed Coatings}

The identification of iron-containing phases in the samples was done on the basis of hyperfine parameters, such as the hyperfine field, isomer shift, and quadrupole splitting, 
which were determined for the particular spectral components. Isomer shift values are related to the $\alpha$-Fe standard. The conversion electron Mössbauer spectra measured as a function of annealing temperature of the coating are shown in Figure 12. The CEMS spectra revealed a distribution of Fe atoms in two magnetic and two paramagnetic Fe-Al environments in the annealed coatings.

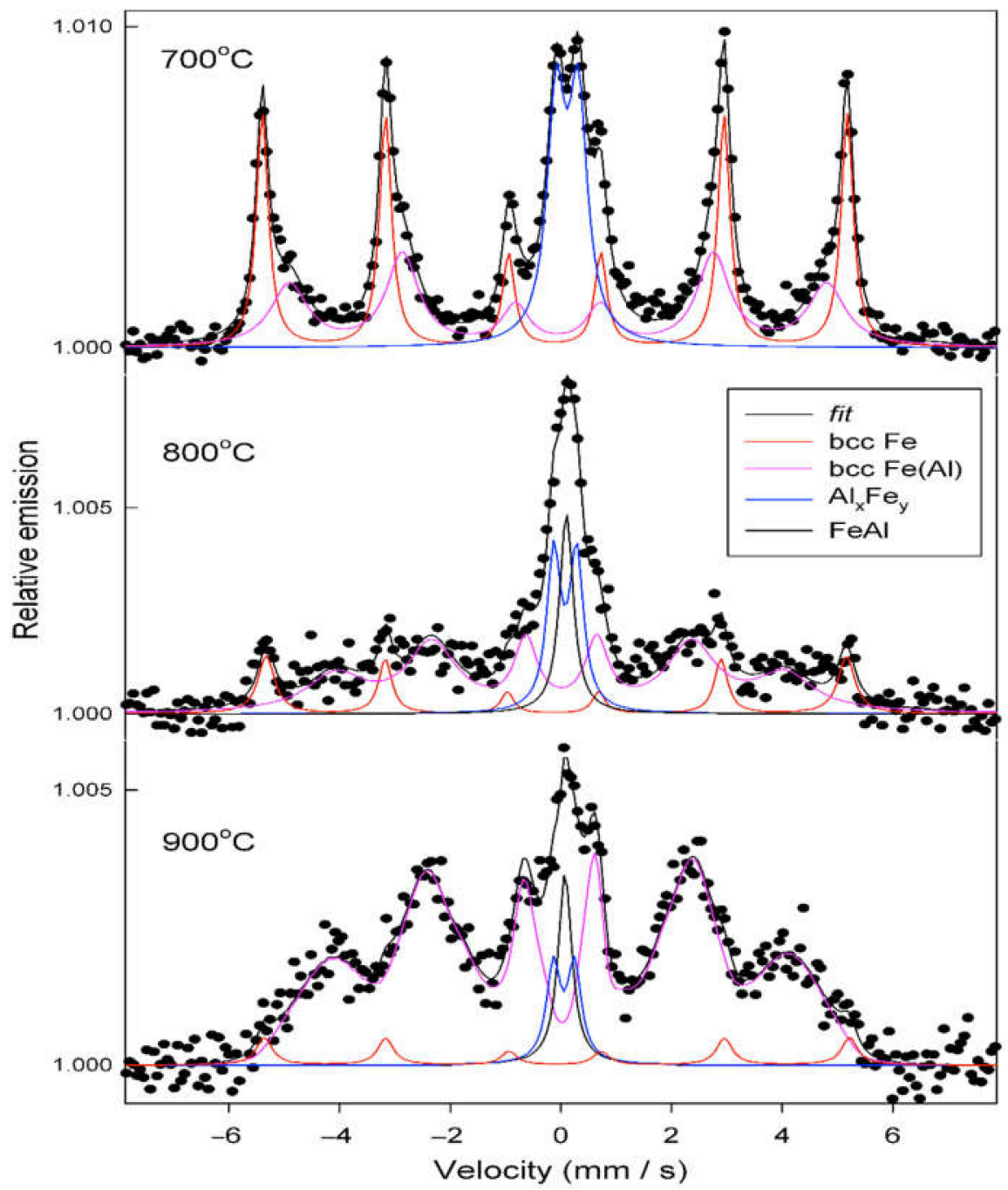

Figure 12. Conversion electron Mössbauer spectra of the coatings annealed at $700-900{ }^{\circ} \mathrm{C}$.

The qualitative and quantitative analyses of the phase composition were performed based on fitting of the spectra with the use of the following spectral components:

- A magnetically split component (sextet) with the hyperfine field of $32.7 \mathrm{~T}$, assigned to bcc Fe atomic environments without $\mathrm{Al}$ atoms as the nearest neighbors; however, some $\mathrm{Al}$ atoms were present in the remote vicinity of Fe atoms, thus causing a reduction of the hyperfine field of $32.95 \mathrm{~T}$, characteristic for the pure bcc Fe phase $[10,48,49]$;

- A sextet with broad lines and average hyperfine field values in the range of 25-30 T, originating from bcc $\mathrm{Fe}(\mathrm{Al})$ disordered solid solution;

- A quadrupole doublet with the quadrupole splitting of $0.40-0.44 \mathrm{~mm} / \mathrm{s}$ and the isomer shift ranging from 0.19 to $0.23 \mathrm{~mm} / \mathrm{s}$, assigned to a paramagnetic Al-rich $\mathrm{Al}_{\mathrm{x}} \mathrm{Fe}_{\mathrm{y}}$ phase;

- A single line with the isomer shift of $0.22 \mathrm{~mm} / \mathrm{s}$, assigned to a paramagnetic intermetallic bcc FeAl phase. 
The CEMS spectrum obtained after annealing at $700{ }^{\circ} \mathrm{C}$ was qualitatively similar to the spectrum of the untreated sample studied previously [10]. It consisted of the same three spectral components (1)-(3); however, the contribution of the quadrupole doublet (3) related to the formation of the Al-rich $\mathrm{Al}_{x} \mathrm{Fe}_{y}$ phase was markedly larger than for the unannealed sample. Annealing at $800-900{ }^{\circ} \mathrm{C}$ induced structural changes in the Fe-Al coating, which were clearly seen in the CEMS spectra as the intensity of the bcc Fe spectral component (1), dominating at $700{ }^{\circ} \mathrm{C}$, which decreased significantly at higher temperatures in favor of the components related to binary Fe-Al phases. The broad sextet (2) revealed a distribution of the hyperfine field, particularly observed for the samples annealed at $800-900^{\circ} \mathrm{C}$. The hyperfine field values covered a wide range from about $10 \mathrm{~T}$ up to $33 \mathrm{~T}$. The average values of the hyperfine field of the sextet (2) were approximately $30 \mathrm{~T}$ after annealing at $700{ }^{\circ} \mathrm{C}$ and $25 \mathrm{~T}$ after annealing at $800-900{ }^{\circ} \mathrm{C}$.

This significant decrease of the average hyperfine field value with the increase of the annealing temperature indicates that a substantially larger number of $\mathrm{Al}$ atoms were incorporated into the $\mathrm{Fe}(\mathrm{Al})$ solid solution formed after annealing at $800-900{ }^{\circ} \mathrm{C}$ than at $700{ }^{\circ} \mathrm{C}$. Based on the experimental dependence of the average hyperfine field on the composition of binary iron-rich $\mathrm{Fe}(\mathrm{Al})$ disordered solid solution, it was estimated that the percent of solute $\mathrm{Al}$ atoms increased from about $15 \%$ to about $28 \%$ after annealing at $700{ }^{\circ} \mathrm{C}$ and $800-900{ }^{\circ} \mathrm{C}$, respectively $[48,49]$.

Furthermore, a significant increase of the relative spectral fraction of the sextet (2) from $36 \%$ for the sample annealed at $700{ }^{\circ} \mathrm{C}$ to $56 \%$ and $83 \%$ after annealing at $800{ }^{\circ} \mathrm{C}$ and $900{ }^{\circ} \mathrm{C}$, respectively, strongly indicates that the higher the annealing temperature, the more effective formation of the $\mathrm{Fe}(\mathrm{Al})$ solid solution.

Thermally induced changes in the magnetic Fe-Al environments were accompanied also by the evolution of paramagnetic components in the CEMS spectra. The quadrupole doublet observed after annealing at $700{ }^{\circ} \mathrm{C}$ was partially replaced by a single line after annealing at higher temperatures. As concerns the quadrupole doublet (3), its hyperfine parameters suggest the formation of an Al-rich phase with a composition close to $\mathrm{Al}_{5} \mathrm{Fe}_{2}[10,50]$, in good agreement with the XRD data. The appearance of the single line (4) after annealing at 800 and $900{ }^{\circ} \mathrm{C}$ strongly indicates the formation of cubic FeAl phase. The isomer shift of the single line was, however, considerably smaller than that characteristic of the ordered intermetallic FeAl phase with the equiatomic composition $[49,50]$. This fact suggests a non-stoichiometric ratio of the intermetallic phase, i.e., an excess of iron. The relative fraction of the intermetallic spectral component did not exceed $11 \%$. Traces of paramagnetic iron oxides cannot be excluded.

The Mössbauer spectroscopy measurements showed that annealing induced further mixing of iron and aluminum in the samples so that the coating annealed at the highest temperature applied $\left(900^{\circ} \mathrm{C}\right)$ revealed the most homogenous structure, consisting predominantly of the bcc solid solution with an estimated average composition of $\mathrm{Fe}_{72} \mathrm{Al}_{28}$. The presence of a small amount of the intermetallic non-stoichiometric FeAl phase was also observed.

\subsection{Hardness Analysis}

Microhardness analysis has been conducted on the specimens for the cross-section of the coating/substrate system. The Vickers method was used (load $100 \mathrm{~g}$ for $10 \mathrm{~s}$ ). Hardness analysis was realized by means of the Leitz-Wetzlar microhardness tester (LEICA, Wetzlar, Germany). In order to determine the uncertainty of measurement, $t$-student distribution was conducted, with a confidence level assumed at $95 \%$. The obtained results were used to create a chart that presents the distribution of hardness.

The microhardness distribution presented in Figure 13 indicates significant differences in the hardness of the arc-spray-deposited coating before annealing and the coatings after the annealing processes, with three different temperature conditions described in heading 2. 


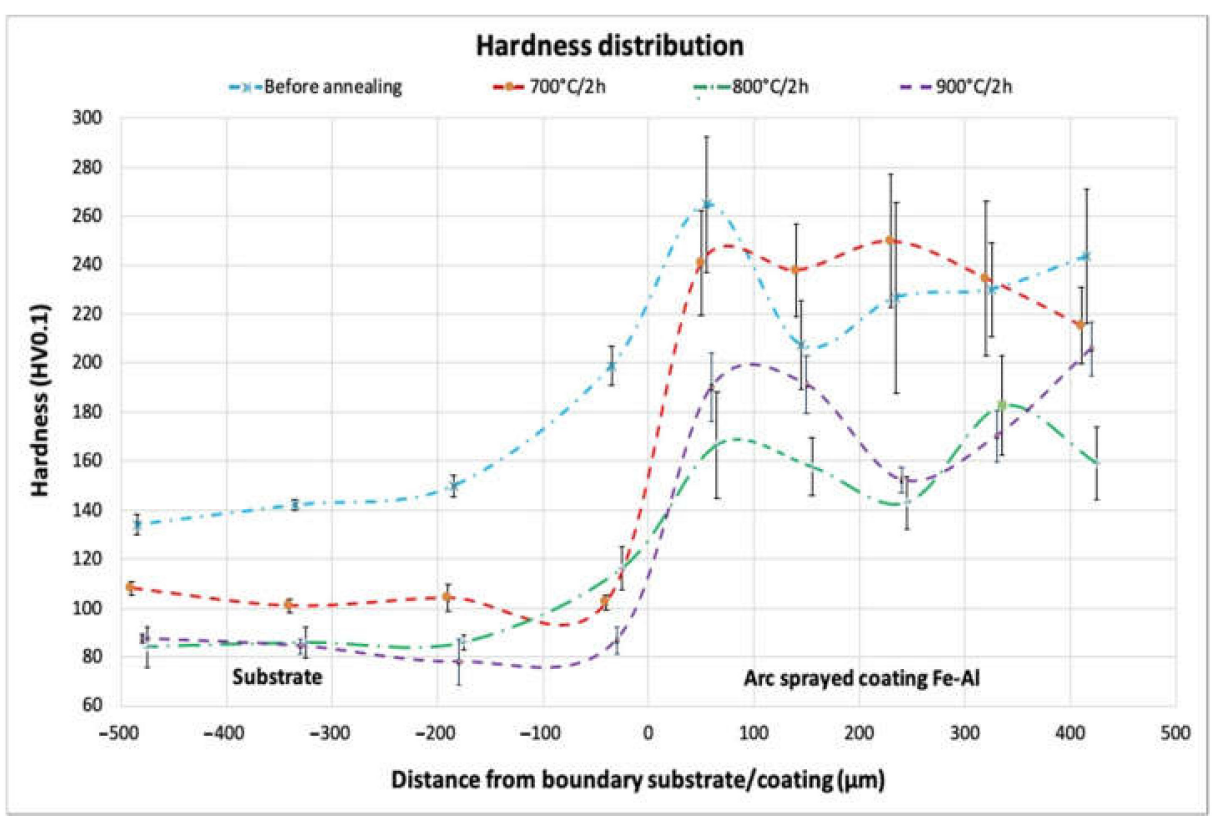

Figure 13. Distribution of microhardness in the cross-section of the substrate material and the arc-sprayed Fe-Al coating, before and after annealing at temperatures $700{ }^{\circ} \mathrm{C}, 800{ }^{\circ} \mathrm{C}$, and $900{ }^{\circ} \mathrm{C}$.

Annealing at a temperature of $700{ }^{\circ} \mathrm{C}$ did not significantly affect the hardness of the coating; it was comparable with the state before annealing. In addition, a hardness decrease in the steel substrate of approximately $40 \mathrm{HV} 0.1$ was observed for all annealing treatments carried out. Annealing at a temperature of $800{ }^{\circ} \mathrm{C}$ caused a noticeable decrease in hardness in the coating by about $80 \mathrm{HV}$, as an additional effect a reduction in the standard deviation value was observed compared to the untreated coating and the coating annealed at $700{ }^{\circ} \mathrm{C}$. The hardness of the annealed coating at $900{ }^{\circ} \mathrm{C}$ was between the hardness of the annealed coatings at $700{ }^{\circ} \mathrm{C}$ and $800{ }^{\circ} \mathrm{C}$. In addition, a significant decrease in the value of the standard deviation from the average was noted (for $900{ }^{\circ} \mathrm{C}$ it was the lowest among the examined cases, Table 4), which indicates changes in the structure towards homogeneity.

Table 4. Hardness distribution in cross-section of substrate coating system, before and after annealing; the table shows the average value and standard deviation for the hardness distributions for the charts from Figure 12.

\begin{tabular}{|c|c|c|c|c|c|c|c|c|c|}
\hline \multirow{3}{*}{$\begin{array}{c}\text { State } \\
\text { of the Coating }\end{array}$} & \multicolumn{9}{|c|}{ Hardness Distribution, HV0.1 } \\
\hline & \multicolumn{9}{|c|}{ Approximately Distance from Boundary Substrate/Coating, $\mu \mathrm{m}$} \\
\hline & -470 & -325 & -180 & -35 & 55 & 150 & 240 & 330 & 420 \\
\hline $\begin{array}{c}\text { Before } \\
\text { annealing }\end{array}$ & $\begin{array}{c}134 \\
(7.91)\end{array}$ & $\begin{array}{c}142 \\
(4.3)\end{array}$ & $\begin{array}{c}149 \\
(8.32)\end{array}$ & $\begin{array}{c}198 \\
(15.99)\end{array}$ & $\begin{array}{l}264.75 \\
(55.36)\end{array}$ & $\begin{array}{l}207.25 \\
(36.31)\end{array}$ & $\begin{array}{l}226.75 \\
(77.82)\end{array}$ & $\begin{array}{c}230 \\
(38.22)\end{array}$ & $\begin{array}{c}243.5 \\
(54.55)\end{array}$ \\
\hline $700^{\circ} \mathrm{C}$ & $\begin{array}{c}108 \\
(5.87)\end{array}$ & $\begin{array}{c}100.83 \\
(5.7)\end{array}$ & $\begin{array}{l}104.05 \\
(10.73)\end{array}$ & $\begin{array}{l}102.3 \\
(5.81)\end{array}$ & $\begin{array}{l}240.75 \\
(42.7)\end{array}$ & $\begin{array}{l}237.75 \\
(37.66)\end{array}$ & $\begin{array}{l}249.75 \\
(54.5)\end{array}$ & $\begin{array}{c}234.5 \\
(63.37)\end{array}$ & $\begin{array}{l}215.25 \\
(31.59)\end{array}$ \\
\hline $800^{\circ} \mathrm{C}$ & $\begin{array}{c}84.03 \\
(16.46)\end{array}$ & $\begin{array}{c}85.75 \\
(12.53)\end{array}$ & $\begin{array}{l}85.85 \\
(5.85)\end{array}$ & $\begin{array}{c}116.4 \\
(17.82)\end{array}$ & $\begin{array}{c}166.5 \\
(43.87)\end{array}$ & $\begin{array}{c}157.5 \\
(23.69)\end{array}$ & $\begin{array}{c}143 \\
(21.44)\end{array}$ & $\begin{array}{l}182.5 \\
(40.6)\end{array}$ & $\begin{array}{c}159 \\
(29.67)\end{array}$ \\
\hline $900^{\circ} \mathrm{C}$ & $\begin{array}{l}87.35 \\
(4.12)\end{array}$ & $\begin{array}{l}84.33 \\
(6.24)\end{array}$ & $\begin{array}{c}77.83 \\
(18.38)\end{array}$ & $\begin{array}{c}86.68 \\
(11.11)\end{array}$ & $\begin{array}{c}190 \\
(27.61)\end{array}$ & $\begin{array}{l}191.25 \\
(23.59)\end{array}$ & $\begin{array}{l}152.25 \\
(10.13)\end{array}$ & $\begin{array}{c}170 \\
(20.99)\end{array}$ & $\begin{array}{c}205 \\
(21.83)\end{array}$ \\
\hline
\end{tabular}

\section{Conclusions}

The results of the SEM/EDX, XRD, CEMS, and HV0.1 experiments and analyses allowed for the evaluation of the changes in a chemical/phase composition and the degree 
of hardening in the arc-sprayed $\mathrm{Fe}-\mathrm{Al}$ type coating after annealing at $700{ }^{\circ} \mathrm{C}, 800{ }^{\circ} \mathrm{C}$, and $900{ }^{\circ} \mathrm{C}$ for $2 \mathrm{~h}$.

It was determined that:

- The composite arc-sprayed Fe-Al coating with initial low participation of in situ created intermetallic phases showed significant changes in the phase composition, with an increase in the volume fraction of Fe-Al intermetallic phases as a result of annealing;

- At the lower annealing temperature of $700{ }^{\circ} \mathrm{C}$, besides the $\mathrm{Fe}(\mathrm{Al})$ solid solution, other transitional Al-rich Fe2Al5 intermetallic phases were formed;

- An increase in the heating temperature induced further diffusion of $\mathrm{Al}$ and the formation of different Fe-Al-type phases, namely, bcc Fe(Al) solid solution and disordered intermetallic FexAly phases with varying chemical compositions (according to the $\mathrm{Fe}-\mathrm{Al}$ equilibrium system);

- The thermal activation at $800{ }^{\circ} \mathrm{C}$ and $900{ }^{\circ} \mathrm{C}$ for $2 \mathrm{~h}$ stimulated the formation of the FeAl intermetallic phase, with specific $\{100\}$ reflection originating from a superlattice with B2 ordering (as confirmed in XRD investigations);

- A significant decrease of the bcc Fe metallic phase (from the range of $50 \%$ to about $5 \%$ ) in the arc-sprayed Fe-Al coating was observed, with the increase of annealing temperature up to $900{ }^{\circ} \mathrm{C} / 2 \mathrm{~h}$;

- The volume fraction of the B2 ordered FeAl phase increased with increasing annealing temperature;

- After annealing at the temperature of $900{ }^{\circ} \mathrm{C}$, the structure was composed of a B2 ordered $\mathrm{FeAl}$ intermetallic phase and disordered $\mathrm{Fe}_{3} \mathrm{Al}$ secondary solution, confirmed in the Mössbauer spectroscopy investigation;

- Heating of the arc-sprayed Fe-Al coating at a temperature of $900^{\circ} \mathrm{C}$ for $2 \mathrm{~h}$ initiated the geometrical changes of lamellar structure, which ensured more homogeneity but was still not quite uniform in the SEM/EDX analysis;

- The microhardness distribution indicated significant differences in the hardness of the coatings after the annealing processes with three different temperature conditions;

- Annealing at temperatures of $800{ }^{\circ} \mathrm{C}$ and $900{ }^{\circ} \mathrm{C}$ caused a noticeable decrease in hardness;

- An additional effect was the reduction of the value of the standard deviation of the mean hardness value with the increase of the annealing temperature. The highest decrease in the value of the standard deviation from the mean hardness value occurred after annealing at the temperature of $900{ }^{\circ} \mathrm{C}$, which confirmed the homogeneity changes of the structure.

Author Contributions: Conceptualization, T.C. and P.S.; methodology, M.C.; validation, B.S., M.C., and T.C.; investigation, A.P., A.G., and T.C.; resources, B.S.; data curation, B.S. and P.S.; writingoriginal draft preparation, T.C. and B.S.; writing-review and editing, T.C. and M.C., visualization, B.S.; supervision, T.C. and P.S.; designed and performed the experiments, M.C., P.S.; SEM, EDS spectroscopy, A.P.; Mössbauer spectroscopy, A.G. All authors have read and agreed to the published version of the manuscript.

Funding: The publication of the study was co-funded using the statutory subsidy of the Faculty of Production Engineering of the Warsaw University of Technology in 2019.

Institutional Review Board Statement: Not applicable.

Informed Consent Statement: Not applicable.

Data Availability Statement: Not applicable.

Acknowledgments: Thanks are given to the assistance from the SciTeeX company for arc spraying process.

Conflicts of Interest: The authors declare no conflict of interest. 


\section{References}

1. Zamanzade, M.; Barnoush, A.; Motz, H. A review on the properties of iron aluminide intermetallics. Crystals 2016, 6, 10. [CrossRef]

2. Lisiecki, A.; Ślizak, D. Hybrid laser deposition of fe-based metallic powder under cryogenic conditions. Metals 2020, 10, 190. [CrossRef]

3. Ye, H.; Peng, S.; Yan, Z.; Zhang, X. Microstructure and properties of laser cladding Fe-Al intermetallics. Adv. Mater. Res. 2013, 659, 39-42. [CrossRef]

4. Wołczyński, W.; Senderowski, C.; Morgiel, J.; Garzeł, G. D-gun sprayed Fe-Al single particle solidification. Arch. Metall. Mater. 2014, 59, 211-220. [CrossRef]

5. Pawłowski, A.; Senderowski, C.; Wołczyński, W.; Morgiel, J. Major Detonation deposited Fe-Al coatings Part II: Transmission electron microscopy of interlayers and Fe-Al intermetallic coating detonation sprayed onto the 045 steel substrate. Arch. Metall. Mater. 2011, 59, 211-220. [CrossRef]

6. Pawłowski, A.; Czeppe, T.; Senderowski, C. Structure morphology of Fe-Al coating detonation sprayed onto carbon steel substrate. Arch. Metall. Mater. 2009, 54, 783-788.

7. Górka, J.; Czupryński, A.; Zuk, M.; Adamiak, M.; Kopyść, A. Properties and structure of deposited nanocrystalline coatings in relation to selected construction materials resistant to abrasive wear. Materials 2018, 11, 1184. [CrossRef] [PubMed]

8. Szczucka-Lasota, B.; Wegrzyn, T.; Stanik, Z.; Piwnik, J.; Sidun, P. Selected parameters of micro-jet cooling gases in hybrid spraying process. Arch. Metall. Mater. 2016, 61, 621-624. [CrossRef]

9. Czupryński, A.; Gorka, J.; Adamiak, M. Examining properties of arc sprayed nanostructured coatings. Metalurgija 2016, 55, 173-176.

10. Chmielewski, T.; Siwek, P.; Chmielewski, M.; Piątkowska, A.; Grabias, A.; Golański, D. Structure and selected properties of arc sprayed coatings containing in-situ fabricated Fe-Al intermetallic phases. Metals 2018, 8, 1059. [CrossRef]

11. Xu, B.; Zhu, Z.; Ma, S.; Zhang, W.; Liu, W. Sliding wear behavior of Fe-Al and Fe-Al/WC coatings prepared by high velocity arc spraying. Wear 2004, 257, 1089-1095. [CrossRef]

12. Cinca, N.; List, A.; Gärtner, F.; Guilemany, J.M. Influence of spraying parameters on cold gas spraying of iron aluminide intermetallics. Surf. Coat. Technol. 2015, 268, 99-107. [CrossRef]

13. Bober, M. Composite coatings deposited by plasma transfer-Characteristics and formation. Weld. Int. 2015, 29, 946-950. [CrossRef]

14. Cinca, N.; Guilemany, J.M. Thermal spraying of transition metal aluminides: An overview. Intermetallics 2012, 24, 60-72. [CrossRef]

15. Shishkovsky, I.V. Laser-controlled intermetallics synthesis during surface cladding. In Laser Surface Engineering: Processes and Applications; Woodhead Publishing: Sawston, UK, 2015; pp. 237-286. ISBN 9781782420798.

16. Nordmann, J.; Thiem, P.; Cinca, N.; Naumenko, K.; Kruger, M. Analysis of iron aluminide coated beams under creep conditions in high-temperature four-point bending tests. J. Strain Anal. Eng. Des. 2018, 53, 255-265. [CrossRef]

17. Doleker, K.M. The Examination of Microstructure and Thermal Oxidation Behavior of Laser-Remelted High-Velocity Oxygen Liquid Fuel Fe/Al Coating. J. Mater. Eng. Perform. 2020, 29, 3220-3232. [CrossRef]

18. Jozwik, P.; Bojar, Z.; Kołodziejczak, P. Microjoining of Ni3Al based intermetallic thin foils. Mater. Sci. Technol. 2010, 26, 473-477. [CrossRef]

19. Guilemany, J.M.; Cinca, N.; Fernández, J.; Sampath, S. Erosion, abrasive, and friction wear behavior of iron aluminide coatings sprayed by HVOF. J. Therm. Spray Technol. 2008, 17, 762-773. [CrossRef]

20. Szala, M.; Hejwowski, T. Zwiększanie odporności kawitacyjnej stopów metali przez napawanie powłok. Weld. Technol. Rev. 2015, 87, 57-60. [CrossRef]

21. Szala, M.; Walczak, M.; Pasierbiewicz, K.; Kamiński, M. Cavitation erosion and slidingwear mechanisms of AlTiN and TiAlN films deposited on stainless steel substrate. Coatings 2019, 9, 340. [CrossRef]

22. Chmielewski, T.; Hudycz, M.; Krajewski, A.; Salaciński, T.; Skowrońska, B.; Świercz, R. Structure investigation of titanium metallization coating deposited onto AlN ceramics substrate by means of friction surfacing process. Coatings 2019, 9, 845. [CrossRef]

23. Tomków, J.; Rogalski, G.; Fydrych, D.; Labanowski, J. Advantages of the application of the temper bead welding technique during wet welding. Materials 2019, 16, 915. [CrossRef]

24. Rajasekaran, R.; Lakshminarayanan, A.K.; Vasudevan, M.; Vasantharaja, P. Role of welding processes on microstructure and mechanical properties of nuclear grade stainless steel joints. Proc. Inst. Mech. Eng. Part L J. Mater. Des. Appl. 2019, 233, $2335-2351$. [CrossRef]

25. Adamiak, M.; Górka, J.; Kik, T. Structure analysis of welded joints of wear resistant plate and constructional steel. Arch. Mater. Sci. Eng. 2010, 46, 108-114.

26. Tomków, J.; Fydrych, D.; Rogalski, G. Role of bead sequence in underwaterwelding. Materials 2019, 12, 3372. [CrossRef]

27. Wołosz, K.J.; Wernik, J. On the heat in the nozzle of the industrial pneumatic pulsator. Acta Mech. 2016, 227, 1111-1122. [CrossRef]

28. Senderowski, C.; Cinca, N.; Dosta, S.; Cano, I.G.; Guilemany, J.M. The Effect of Hot Treatment on Composition and Microstructure of HVOF Iron Aluminide Coatings in $\mathrm{Na}_{2} \mathrm{SO}_{4}$ Molten Salts. J. Therm. Spray Technol. 2019, 28, 1492-1510. [CrossRef] 
29. Wernik, J.; Wolosz, K.J. Study of heat transfer in fins of pneumatic pulsator using thermal imaging. Chem. Eng. Trans. 2015, 45, 985-990. [CrossRef]

30. Hodulova, E.; Ramos, A.S.; Kolenak, R.; Kostolny, I.; Simekova, B.; Kovarikova, I. Characterization of ultrasonic soldering of Ti and $\mathrm{Ni}$ with $\mathrm{Ni} / \mathrm{Al}$ reactive multilayer deposition. Weld. Technol. Rev. 2019, 91, 51-57. [CrossRef]

31. Hong, L.; Xuan, L.; Haixin, H. Microstructure and properties of ZrO2 ceramic and Ti-6A-4V alloy vacuum brazed by Ti-28Ni filler metal. Weld. Technol. Rev. 2019, 91, 35-41. [CrossRef]

32. Shishkovsky, I.; Missemer, F.; Kakovkina, N.; Smurov, I. Intermetallics synthesis in the Fe-Al system via layer by layer 3D laser cladding. Crystals 2013, 3, 517-529. [CrossRef]

33. Sun, K.; Cheng, J.; Liu, X.; Fang, L.; Ma, L. In-Situ Fabrication of Fe-Al Intermetallic Coating by Laser Remelting. J. Mechatron. 2014. [CrossRef]

34. Ma, H.; Ren, K.; Xiao, X.; Qiu, R.; Shi, H. Growth characterization of intermetallic compounds at the Cu/ Al solid state interface. Mater. Res. Express 2019, 6, 1-11. [CrossRef]

35. Chu, Y.J.; Li, X.Q.; Li, J.; Yang, F.; Yang, S.F. Effects of annealing temperature on microstructure and properties of AlFeCrCoNiTi high-entropy alloy coating prepared by laser cladding. Cailiao Rechuli Xuebao/Trans. Mater. Heat Treat. 2018. [CrossRef]

36. Kik, T.; Moravec, J.; Novakova, I. New method of processing heat treatment experiments with numerical simulation support. In Proceedings of the IOP Conference Series: Materials Science and Engineering, Hong Kong, China, 12-14 December 2017; p. 227.

37. Winczek, J.; Gawronska, E.; Gucwa, M.; Sczygiol, N. Theoretical and experimental investigation of temperature and phase transformation during SAW overlaying. Appl. Sci. 2019, 9, 1472. [CrossRef]

38. Deevi, S.C.; Sikka, V.K. Nickel and iron aluminides: An overview on properties, processing, and applications. Intermetallics 1996, 4, 357-375. [CrossRef]

39. Sun, Y.; Zhang, Z.; Jin, X.; Xu, B.; Zhao, G. Cutting force models for Fe-Al-based coating processed by a compound NC machine tool. Int. J. Adv. Manuf. Technol. 2015, 79, 693-704. [CrossRef]

40. Cegan, T.; Petlak, D.; Skotnicova, K.; Jurica, J.; Smetana, B.; Zla, S. Metallurgical preparation of Nb-Al and W-Al intermetallic compounds and characterization of their microstructure and phase transformations by DTA technique. Molecules 2020, $25,2001$. [CrossRef]

41. Spyra, J.; Michalak, M.; Niemiec, A.; Łatka, L.A. Mechanical properties investigations of the plasma sprayed coatings based on alumina powder. Weld. Technol. Rev. 2020, 92, 17-23. [CrossRef]

42. Dean, S.W.; Potter, J.K.; Yetter, R.A.; Eden, T.J.; Champagne, V.; Trexler, M. Energetic intermetallic materials formed by cold spray. Intermetallics 2013, 43, 121-130. [CrossRef]

43. Novák, P.; Michalcová, A.; Marek, I.; Mudrová, M.; Saksl, K.; Bednarčík, J.; Zikmund, P.; Vojtěch, D. On the formation of intermetallics in Fe-Al system-An in situ XRD study. Intermetallics 2013, 32, 127-136. [CrossRef]

44. Wang, H.T.; Li, C.J.; Yang, G.J.; Li, C.X. Cold spraying of Fe/Al powder mixture: Coating characteristics and influence of heat treatment on the phase structure. Appl. Surf. Sci. 2008, 255, 2538-2544. [CrossRef]

45. Naoi, D.; Kajihara, M. Growth behavior of $\mathrm{Fe}_{2} \mathrm{Al}_{5}$ during reactive diffusion between $\mathrm{Fe}$ and $\mathrm{Al}$ at solid-state temperatures. Mater. Sci. Eng. A 2007, 459, 375-382. [CrossRef]

46. Pawlowski, L. Thermal Spraying Techniques. In The Science and Engineering of Thermal Spray Coatings; John Wiley \& Sons: Hoboken, NJ, USA, 2008; pp. 67-113.

47. Michalak, M.; Łatka, L.; Sokołowski, P.; Niemiec, A.; Ambroziak, A. The microstructure and selected mechanical properties of $\mathrm{Al}_{2} \mathrm{O}_{3}+13$ wt \% $\mathrm{TiO}_{2}$ plasma sprayed coatings. Coatings 2020, 10, 173. [CrossRef]

48. Perez Alcazar, G.A.; Galvao Da Silva, E. Mossbauer effect study of magnetic properties of Fe1-qAl q, 0. J. Phys. F Met. Phys. 1987, 17, 2323-2335. [CrossRef]

49. Krasnowski, M.; Grabias, A.; Kulik, T. Phase transformations during mechanical alloying of Fe-50\% $\mathrm{Al}$ and subsequent heating of the milling product. J. Alloys Compd. 2006, 424, 119-127. [CrossRef]

50. Nasu, S.; Gonser, U.; Preston, R.S. Defects and phases of iron in aluminium. J. Phys. Colloq. 1980, 41, 385-386. [CrossRef] 